\title{
筐体内に配置された電波吸収体の効果的な電磁界抑制に 対する一検討
}

\author{
小玉 和輝 ${ }^{*}$, 小野 裕司 ${ }^{* *}$, 和田 光司 ${ }^{*}$, 橋本 修*
}

\section{A Study on Effective Suppression of Electromagnetic Field by an Absorbing Material Inserted into a Cavity Resonator}

Kazuteru KODAMA ${ }^{*}$, Hiroshi ONO** ${ }^{*}$,Kouji WADA* and Osamu HASHIMOTO*

*青山学院大学理工学部 ( $157-8572$ 東京都世田谷区千歳台6-16-1)

**株式会社トーキン（テ982-8510 宮城県仙台市太白区太子堂21-1）

*College of Science and Engineering, Aoyama Gakuin University (6-16-1 Chitosedai, Setagaya-ku, Tokyo 157-8572)

**Tokin corporation (21-1 Taishidou, Tashiro-ku, Sendai-shi, Miyagi 982-8510)

概要 本論文では，近傍電磁界に対する電波吸収体の評価法である，筐体内に電波吸収体を配置した場合のQ值の低下率 から吸収量を評価する方法に対し, FDTD法による計算值と測定値の比較㧍よび筐体内の磁界分布の解析を行った。この結果， 筐体内に電波吸収体としてフェライト材を装荷した場合のQ值の低下率が，装荷位置を変えた場合においても計算值と測定値 において，それぞれ2\%以下の違いで良好に一致することにより，この評価法におけるFDTD法の有効性を確認した。さらに， 筐体内部の磁界強度が電波吸収体を装荷することにより，筐体内全体において抑制されることを定量的に確認することで，今 後の近傍電磁界の効果的な抑制に対するFDTD法の有用性を示すことができた。

\begin{abstract}
Validity of finite difference time domain (FDTD) method is examined by evaluating the absorption performance from the variation of $\mathrm{Q}$ factor under the condition that the absorbing material is inserted into a cavity resonator. The magnetic field distribution in a cavity resonator is visually observed. As a result, we confirmed that the decreasing rate of $Q$ factor was agreed with the calculated and measured results, and both corresponded in the difference in 2 percent. Consequently, validity of FDTD method for examination mentioned above is confirmed. We confirmed that magnetic field distribution in the cavity resonator was drastically weaken when the absorbing material is inserted into the cavity resonator.
\end{abstract}

Key Words: Near Electromagnetic Field, Absorbing Materials, Q Factor, FDTD Method

\section{1. まえがき}

マイクロ波,ミリ波帯における電子機器の実用化に伴い, 筐体内において使用されるIC等がノイズ源として働き, 電磁界結合や共振現象が生じることにより，他の素子に悪

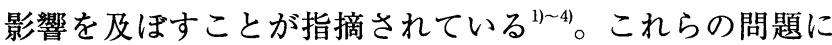
対する対策法として，例えば，筐体内に電波吸収体を配置 し，各素子間の電磁界結合や共振現象を緩和することが考 えられている 5 (5)。しかし，筐体内の電波吸収体はノイズ 源の近傍電磁界中に配置されることになり，通常市販され ている遠方電磁界に対して設計された電波吸収体では，そ の吸収効果がどの程度保証されるかわからないのが実状で ある。

このような背景において，近傍電磁界に対する電波吸収 体の評価法として，(1)対象とする電波吸収体の近傍に微 小ループアンテナを配置して，そのカップリングの変化か ら吸収効果を評価する方法 ${ }^{10} や ，(2)$ 実際に筐体内に電波吸 収体を装荷した場合のQ值より評価する方法 ${ }^{11}$ が報告され ている。本論文では，これらのうち後者の評価法に着目し，
筐体モデルとして方形空洞共振器を用い，その内部に電波 吸収体としてフェライト材料を装荷した場合のQ值を FDTD法を用いて計算し，測定値と比較検討を行った。ま た，電波吸収体を装荷した場合の筐体内における電磁界の 抑制効果を視覚的に確認するため，筐体内の磁界強度分布 を観察した。これらの結果より，Q值に着目した近傍電磁 界の抑制効果の評価法やその効果的な抑制に対するFDTD 法の有効性および有用性を検討した。

\section{2. 解 析}

\section{1 解析方法}

本解析では，Fig. 1 に示すTE $\mathrm{T}_{101}$ モードにおいて共振周波 数 $f_{0}=1.18 \mathrm{GHz}$ の方形空洞共振器 $(180 \mathrm{~mm} \times 90 \mathrm{~mm} \times$ $180 \mathrm{~mm})$ を用い，そのセルサイズ（ $\Delta x, \Delta y, \Delta z)$ は $(1.14 \mathrm{~mm}, 2.00 \mathrm{~mm}, 2.00 \mathrm{~mm})$ とした。測定で用いる共振 器の導体壁は銀で構成されており，その導電率は一般に $\sigma=6.29 \times 10^{7}[\mathrm{~S} / \mathrm{m}]$ であることが知られているが，酸化等の 影響により実際には, 多少変化している。そこで解析では, 共振器内に何も装荷されていない状態においてQ值の計算 


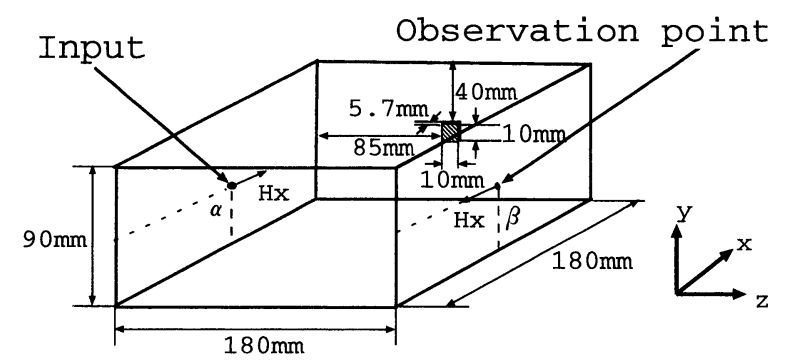

Fig.1 Analytical model of resonator

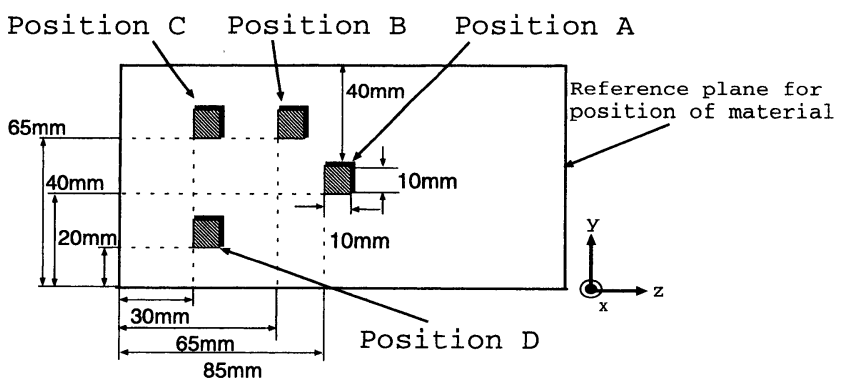

Fig.2 Attachment position of material

值が測定值と一致するように導電率を測定値から推定し, ここでは $\sigma=3.465 \times 10^{7}[\mathrm{~S} / \mathrm{m}]$ とした。

このような構成において, 共振器内に電波吸収体 (以下, 試料と称す）として，厚さ $5.7 \mathrm{mm，大きさ} 10.0 \mathrm{~mm} \times$ 10.0mmのNi-Zn系のフェライトをFig. 2 に示すような励振 面に直交する面の異なる 4 箇所に装荷した場合のQ值を計 算した。

ここで，装荷したフェライトの複素比誘電率 $\left(\dot{\varepsilon}_{r}=\varepsilon_{r}{ }^{\prime}-\right.$ $\left.j \varepsilon_{r}{ }^{\prime \prime}\right)$ および複素比透磁率 $\left(\dot{\mu}_{r}=\mu_{r}^{\prime}-j \mu_{r}{ }^{\prime \prime}\right)$ の摂動法 ${ }^{12}$ を用 いた測定值は， $f_{0}=1.18 \mathrm{GHz} に お い て ， そ れ そ ゙ れ \dot{\varepsilon}_{r}=11.3-$

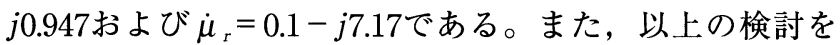
行うと共に，筐体内の電磁界抑制効果を視覚的に確認する ため, Fig. 1 のz面において磁界強度を求め観察した。

\section{$2.2 f_{0}$ の計算}

まずFig. 1 の $\alpha$ 点の磁界 $H_{x}$ 成分に，励振を与えたことに よる影響を考虑せず励振する方法であるハードラテス ${ }^{13} に$ より，幅広い周波数スペクトルを有する式(1)で示すガウ シャンパルスを入力し， $\beta$ 点における磁界 $H_{x}$ 成分の時系列 デー夕を観察した。そして，この観測された時系列デー夕 にFFT処理を施し $f_{0}$ を求めた。

$$
H_{x}(n \Delta t)=e^{-(\mid(n \Delta t-T) / 0.29 T)^{2}}
$$

この式において $f_{0}=1.18 \mathrm{GHz}$ ，周期 $T=0.646 / f_{0}$ とした。 また， $\Delta t$ は時間ステップ, nは繰り返し数である。ここで, FFTにより処理された周波数分解能 $\Delta f$ は

$$
\Delta f=\frac{1}{N \Delta t}
$$

と, 時系列データ数により決まる。本研究では, 計算時間 の関係で，サンプル数 $N=65536$, 時間ステップ $\Delta t=$ $1.354251294 \times 10^{-12} \sec$ で行っているが，このデータをその ままFFT処理すると周波数分解能は $11 \mathrm{MHz}$ となり, 高精 度に $f_{0}$ を求めることができない。そこで, 観察した時系列

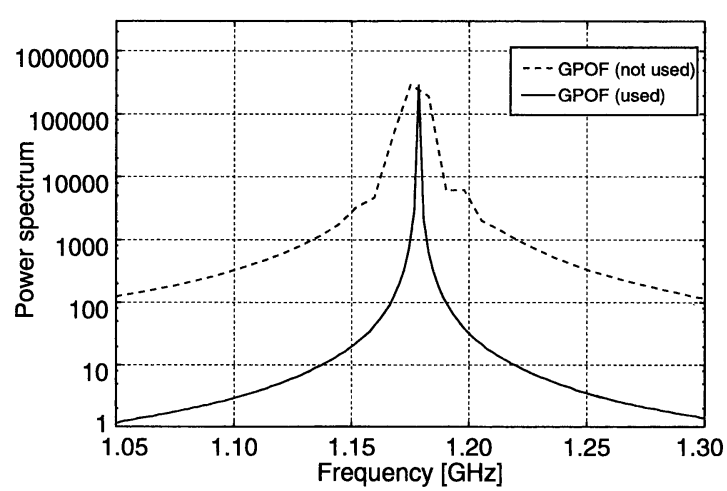

Fig.3 Calculated result of resonant frequency

デー夕にGPOF(Generalized Pencil of Function)法 ${ }^{(4)}$ を施す ことにより，32倍まで外抻した後，FFT処理を施し周波 数分解能を向上させた。Fig. 3 はその結果を示したもので, 試料非装荷時におけるGPOF法を併用した場合と併用しな い場合の $f_{0}$ の比較を示している。この図において横軸は周 波数, 縦軸は周波数スペクトラムであり, 周波数分解能が $0.36 \mathrm{MHz}$ と大幅に向上しており， $f_{0}=1.1778 \mathrm{GHz}$ であこ とがわかった。

なお，FDTD法による計算時間は，コンピュー夕 PentiumIII $(600 \mathrm{MHz})$ を用いて，約 24 時間（約 1 日）であ り, GPOF法を用いずに，今回の周波数分解能を達成する ためには, 約770時間（約 32 日）の計算時間が必要になる と推定される。

\section{2. $3 \mathrm{Q}$ 值の計算}

2.2 より求めた $f_{0}$ のW波を $\alpha$ 点の $H_{x}$ 成分に励振し，七ル 各点における電磁界成分を求め，この電磁界を用いて共振 器内に蓄えられるエネルギの時間平均值 $W$ と共振器内にお いて単位時間当たりに失なわれるエネルギPを計算した。 そして, 得られた $W$ とから, 式(3)を用いてQ值の計算を 行った。

$$
Q=2 \pi f_{0} \frac{W}{P}
$$

Fig. 4 (a)，(b)はそれぞれ試料非装荷時と試料装荷時の計 算周期に対するQ值の計算結果を示している。ここで，横 軸は周期，縦軸はQ值をそれぞれ表している。

結果よりQ值は600周期目において, 試料非装荷時で 18046, 試料装荷時では, 装荷位置Aで911, 装荷位置Bで 1007，装荷位置Cで2429，および装荷位置Dで2424であり， 装荷位置Cの值は装荷位置Dとほとんど変わらないことが 観察できた。ここで, 式(4)からなる低下率を定義すると， 試料を装荷した場合，その值は装荷位置 $\mathrm{A} \sim \mathrm{D}$ の順に 95.0\%，94.4\%，86.5\%㧍よび86.5\%とQ值が大幅に低下し ており，側面の中心部ほど，低下率が高いことが確認でき た。

$$
\text { 低下率 }[\%]=\frac{\text { 試料非装荷時のQ值 }- \text { 試料装荷時のQ值 }}{\text { 試料非装荷時のQ值 }} \times 100
$$




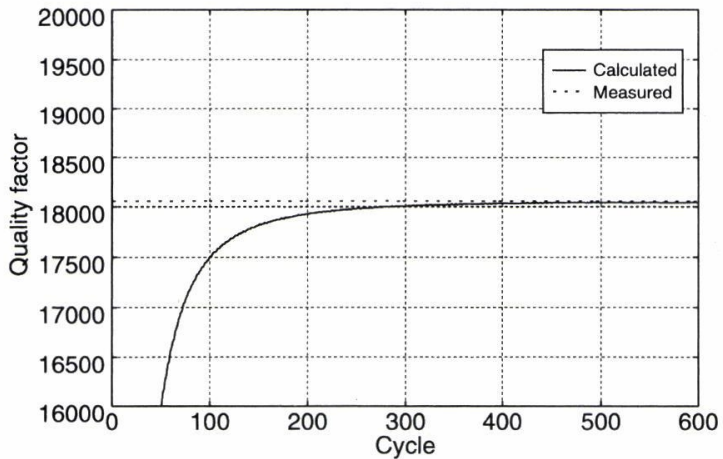

(a) In the case of no material

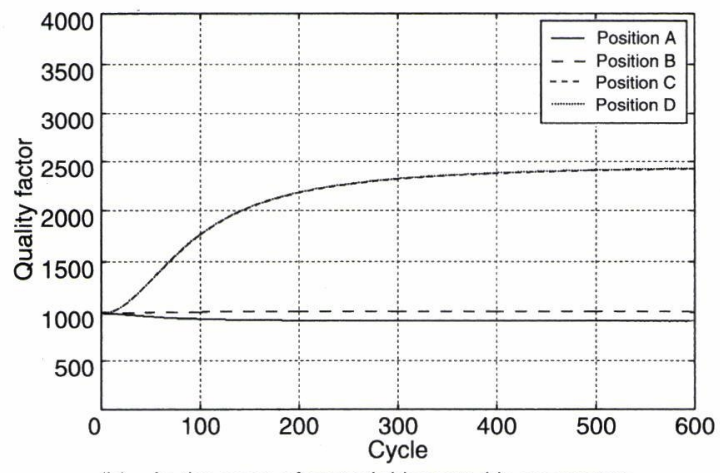

(b) In the case of material inserted in resonator

Fig.4 Calculated result of $Q$ value

\section{3. 測 定}

\section{1 測定系}

方形空洞共振器 (共振周波数 $f_{0}=1.18 \mathrm{GHz}$, 大きさ： $180 \mathrm{~mm} \times 90 \mathrm{~mm} \times 180 \mathrm{~mm})$ を，ベクトルネットワークア ナライザ（HP8510C）に接続し, 共振器内部に扔ける試 料非装荷時と試料装荷時について, Fig. 5 のように透過係 数 $S_{21}$ を測定し, この結果と式(5)を用いることにより Q值を 求めることができる。

$$
Q=\frac{1}{\left(1-10^{\frac{-I L_{0}}{20}}\right) \frac{\Delta f}{f_{0}}}
$$

ここで，共振周波数 $f_{0}, 3 \mathrm{~dB}$ 帯域幅 $\Delta f$ f扔よび扱入損失 $I L_{0}$ である。

Fig. 6 に試料を装荷した共振器の内部構造を示す。また, 筐体とカバーとの間の隙間の影響により，Q值が変化しな いように, 全体で44箅所をネジで固定し, 測定の再現性が

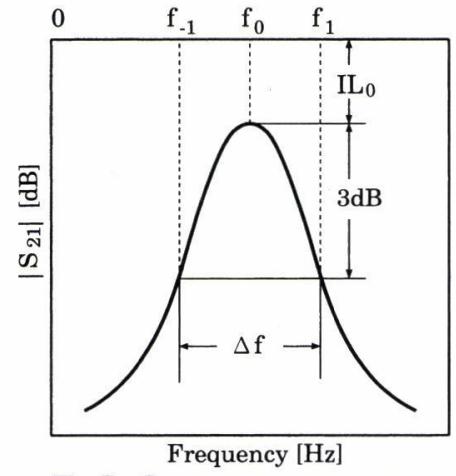

Fig.5 Resonance response

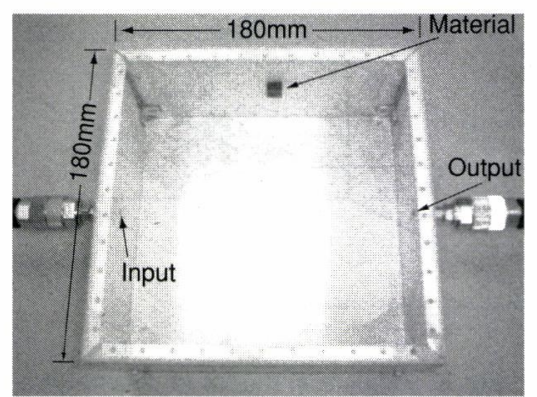

Fig.6 Inside view of resonator

得られるようにした。

\section{2 測定結果}

Table 1 に3.1で述べた測定法により測定した結果を示 す。また, Table 2 に試料非装荷時と試料装荷時のQ值の 測定値，計算值および式(5)を用いたQ值の低下率をまとめ た結果を示す。な扮Table 2 に打いて，低下率を D.R(Decreasing rate)と表している。

Table 1 より，試料を装荷することで $f_{0}$ は低下するが， その影響は小さいこと，またQ值は試料を装荷することで 試料非装荷時に比べて大幅に低下し, その值は装荷位置A で最も低く, 続いてB，C，Dの順に高くなっていくこと がわかった。

そしてTable 2 より, 計算值と測定值において本検討で 用いた試料の場合，わずか $10.0 \mathrm{~mm} \times 10.0 \mathrm{~mm}$ 程度の大きさ の試料を装荷しても，それぞれの装荷位置において筐体内 部のQ值は大きく低下し, 磁界強度を弱める効果があるこ とがわかった。これより，フェライト材のQ值低減に対す る定量的効果を確認することができた。さらに，Q值は側 面の中心である装荷位置Aにおいて最も低下し, 計算值が 911, 測定值が1129であり, その違いを式(4)の低下率で示 すと，95.0\%に対して $93.8 \%$, 両者は1\%程度の誤差で良 好に一致することがわかった。そして装荷位置B〜Dにつ いてもそれぞれ低下率が $2 \%$ 以下の誤差で良好に一致する ことを確認した。なお，計算值と測定値はわずかに異なる が，その理由は，(1)測定において，試料を壁面に固定す るために使用した両面テープの効果を解析において考慮し なかった影響，(2)試料の材料定数の測定誤差等と考えら

Table 1. Measured results of $Q$ values

\begin{tabular}{c|c|c|c|c}
\hline Material & $f_{0} \backslash \mathrm{GHz} \$ & $\Delta f\lfloor\mathrm{MHz}\rfloor$ & $I_{0}\lfloor\mathrm{~dB}\rfloor$ & $Q$ \\
\hline No material & 1.1776 & 0.0675 & 29.1 & 18079 \\
\hline Position A & 1.1767 & 1.045 & 52.5 & 1129 \\
\hline Position B & 1.1768 & 0.885 & 51.3 & 1333 \\
\hline Position C & 1.1773 & 0.451 & 45.0 & 2631 \\
\hline Position D & 1.1771 & 0.428 & 44.9 & 2769 \\
\hline
\end{tabular}

Table 2. Measured and calculated results of $Q$ values

\begin{tabular}{c|c|c|c|c}
\hline Material & Calculated & Measured & D.R(Cal.) 【\%】 & D.R(Mea.) 【\%】 \\
\hline No material & 18046 & 18079 & - & - \\
\hline Position A & 911 & 1129 & 95.0 & 93.8 \\
\hline Position B & 1007 & 1333 & 94.4 & 92.6 \\
\hline Position C & 2429 & 2631 & 86.5 & 85.4 \\
\hline Position D & 2424 & 2769 & 86.5 & 84.7 \\
\hline
\end{tabular}


れる。

また，Q值について，装荷位置において，端からの距離 が等しく高さが異なる場合はほとんどQ值が変化しないの に対し，高さが等しく端からの距離が異なる場合には大き くQ值が変化することがわかった。これは，本検討におい て共振器のモードがTE $\mathrm{E}_{101}$ であり, 磁界強度が側面の中心 部程強くなるためである。

以上の検討結果から，装荷位置を変えて試料を装荷し， Q值の低下率が変化した場合においても計算值と測定値の 差は試料の装荷位置によらず $2 \%$ 以下で良好に一致するこ とがわかり，本検討に対するFDTD法の有効性が確認でき た。

\section{3 磁界強度分布の計算}

Q值に着目した計算結果の傾向を磁界強度においても確 認するため, Fig. 7 におけるxz面の磁界強度分布を，試料 非装荷時と位置Aに試料を装荷した場合について可視化し た結果をFig. 8 (a)，(b)に示す。この図に扔いて，縦軸はx 方向の寸法, 横軸が $z$ 方向の寸法である。また, 磁界強度 の弱い場所程薄く，強い場所程濃く表示されている。Fig. 8 (a)，(b)より，試料を装荷することで，筐体内全体にお

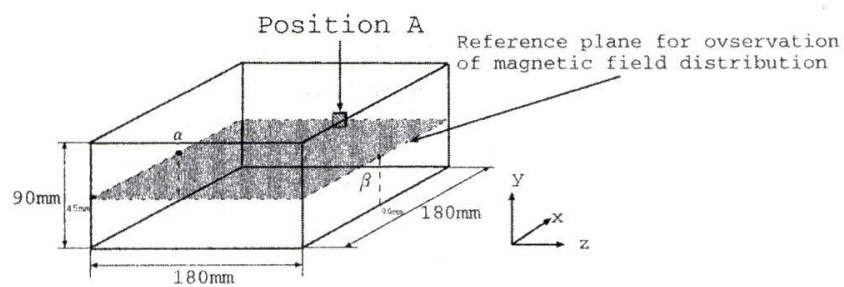

Fig.7 Reference plane for observation of magnetic field distribution

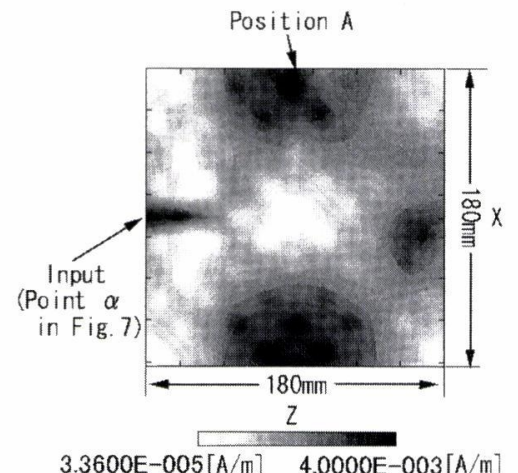

(a) In the case of no material Position A

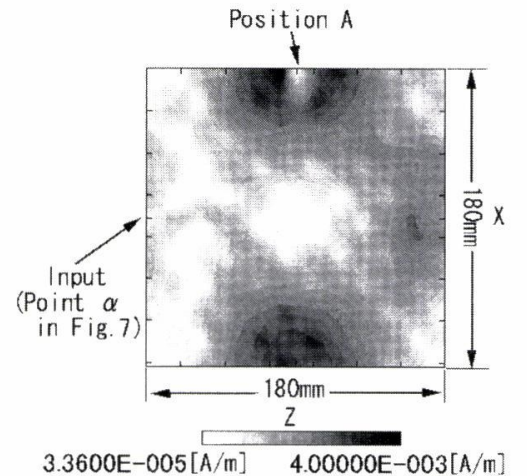

(b) In the case of material inserted in resonator

Fig.8 Magnetic field distributions in resonator
いて試料非装荷時と比べて磁界強度が低下することが確認 できた。特に試料を装荷した場所と側面の中心部において 磁界強度が最も低下していることを確認した。

以上の結果から，試料を筐体内に装荷した場合，装荷し た場所だけでなく，筐体内全体における磁界強度の抑制効 果の分布を確認でき，筐体内へ電波吸収体を配置して，よ り効果的に筐体内の電磁界を低隇する検討に対して，今後 のFDTD法解析の有用性を示すことができた。

\section{4. おわりに}

本論文では，電子機器の筐体として，方形空洞共振器に 電波吸収材を配置した場合のQ值の変化をFDTD法を用い て計算し，測定値と比較することにより，近傍電磁界にお けるQ值に着目した抑制効果評価法や，効果的な電磁界抑 制効果に対する，FDTD法の有効性㧍よび有用性を検討し た結果，次のことがわかった。

(1) 測定值と計算值において，今回の検討で用いたフ エライト材を装荷したことによる $\mathrm{Q}$ 值の低下率は $90 \%$ 前後 であり，また，その差はそれぞれ低下率が変化した場合に おいても試料の装荷位置によらず， $2 \%$ 以下の違いで良好 に一致することがわかり，本解析の有效性を確認した。

（2）筐体側面に試料を装荷した場合， $\mathrm{TE}_{101}$ モードの場 合には側面の中心に試料を装荷する程 $\mathrm{Q}$ 值が低下するこ と，また試料の装荷位置を高さのみ変えた場合にはQ值が ほとんど変化しないのに対し，端からの距離を変えた場合 には大きく変化することを確認した。

(3) 筐体の中央面の磁界強度分布を観察した結果，試 料非装荷時と比較して, 試料装荷時では磁界強度が小さく 抑制されており，その抑制範囲は筐体内全体に及んでいる ことがわかった。そしてこの結果より，Q值の低隇が筐体 内全体のエネルギの低隇であることを磁界強度分布に着目 し視覚的に確認した。

(4) GPOF法を用いることにより，計算時間が大幅に低 減でき，一例として共振周波数の計算時間に扔いて，約 770 時間程度の時間を要する計算を, 約 24 時間程度で行う ことができることがわかった。

以上のことから，近傍電磁界に扔けるQ值に着目した抑 制効果評価法や，筐体内にデバイス等を配置する際の近傍 電磁界に対する，効果的な電磁界抑制効果の検討に対する FDTD法の有効性および有用性が確認できた。また，今後 の課題として，さまざまな試料や筐体を選択した場合の電 磁界強度の抑制の検討が考えられる。

(2001.12.6-受理)

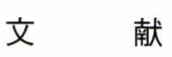

1) A.R.Djordijevic and T.K.Sarkar: "An Investigation of Delta-I Noise on Integrated Circuits", IEEE-Trans.EMC, Vol.35, No.2, pp.134-147, 1993 
2) 原 敦, 笠井真理子, 横田 等, 中村 篤: “基板形状及び ICの電気特性が給電系放射ノイズに与える影響”, 信学技報, EMCJ99-22, pp.35-41, 1999

3）小野恭裕, 秋野直治, 篠原慎一, 佐藤利三郎: “パッヶージ に用いた複合磁性材料によるICからの電磁雑音の抑圧特 性”, 信学技報, EMCJ99-80, pp.23-28, 1999

4) 和田修己, 古賀隆治, 福本幸弘: “IC/LSIのEMC特性測定 における電源系デカップリング”, 信学技報, EMCJ99-101, pp.1-6, 1999

5) 中野 健, 芳賀 知, 橋本 修: “フェライト材を用いた LSIからの放射抑制検討”, EMCJ2001-62，pp.63-68， Oct.2001

6) 芳賀 知, 中野 健, 須藤俊夫 : “LSI動作モードと遠方界 放射への関連”, 信学技報, EMCJ2001-2, pp.7-12, Apr.2001

7) 松原 亮, 宮内啓次, 石田康広, 桑原伸夫, 徳田正満: “コ プレーナストリップライン構造のプリント基板による放射 電磁界抑制効果の検討”, 信学技報, EMCJ2001-45, pp.1-6, Aug.2001
8) T.Akio, et al. : "Reduction Method of Voltage Fluctuation of DC Power Supply in Digital IC", IEICE Trans.on Communications, Vol.E83B, No.3, pp.622-625, Mar.2000

9) 津田文史郎, 小野裕司, 篠原慎一, 佐藤利三郎: “複合磁性 シートの線路装着による伝導電磁雑音の低減効果”, 信学技 報, EMCJ1999-95, pp.37-42, 1999

10) 吉田栄吉：“複合磁性シートを用いた高周波ノイズ対策”, 2000EMC・ノイズ対策技術シンポジウム，4-2-1，2000

11) 橋本康雄, 栗原 宏: “ノイズ対策としての電波吸収体「フ レキシールド」”, 工業材料, Vol.46, No.10, pp.36-40, 1998

12) 橋本 修: “電波吸収体のはなし”, 日刊工業新聞社, 2001

13) 橋本 修, 阿部㻟美: “FDTD時間差分法入門”, 森北出版, 1996

14) Y.Hua and T.K.Sarkar: "Generalized Pencil-of-Function Method for Extracting Poles of an EM System from Its Transient Response”, IEEE Trans. Antennas Propagation, Vol.37, No.2, pp.229-234, 1989 